\title{
Hubungan Tingkat Kebugaran Jasmani Dan Persepsi Siswa Terhadap Hasil Belajar Siswa Dalam Pembelajaran Pendidikan Jasmani
}

\author{
${ }^{1}$ Akhmad Sobarna, ${ }^{2}$ Sumbara Hambali, ${ }^{3}$ Lala Koswara \\ 1Dosen Prodi. Magister Penjas STKIP Pasundan, Cimahi, Jawa Barat, Indonesia \\ ${ }^{2}$ Dosen Prodi. PJKR STKIP Pasundan, Cimahi, Jawa Barat, Indonesia \\ ${ }^{3}$ Mahasiswa Prodi. Magister Penjas STKIP Pasundan, Cimahi, Jawa Barat, Indonesia
}

\begin{abstract}
ABSTRAK
Penelitian ini bertujuan untuk mengetahui hubungan tingkat kebugaran jasmani dan persepsi siswa terhadap hasil belajar siswa. Penelitian ini dilakukan dengan menggunakan metode korelasional. Populasi dan sampel yang digunakan adalah seluruh siswa yang mengikuti pembelajaran pendidikan jasmni, yaitu laki-laki 41 siswa dan perempuan 34 siswa jadi sebanyak 75 orang. Instrumen penelitian ini adalah TKJI 16-19 tahun dan angket. Berdasarkan hasil pengolahan data, disimpulakn bahwa: 1). Tidak ada hubungan yang signifikan antara TKJI terhadap hasil belajar siswa dalam pembelajran pendidikan jasmani yaitu dengan nilai rhitung -0,656 > rtabel 0,514 dengan taraf 5\%, karena nilai rsquare sebesar 0,006 atau setara 0,6\%, korelasi tersebut sangat lemah sehingga diabaikan, karena nilai sebesar 99,4\% tidak ada hubungan 2). Tidak ada hubungan yang signifikan antara Persepsi siswa terhadap hasil belajar siswa dalam pembelajaran pendidikan jasmani yaitu dengan nilai rhitung $-0,191$ $<$ rtabel 0,849 dengan taraf 5\%, sehingga dapat disimpulakan tidak ada hubungan karena nilai rsquare sebesar 0,000 atau setara 0,0\%, 3). Tidak ada hubungan yang signifikan antara TKJI dan Persepsi siswa terhadap hasil belajar siswa dalam pembelajaran pendidikan jasamni yaitu dengan rhitung $\quad-0,678>$ rtabel 0,500 dan rhitung $-0,267<$ rtabel 0,790 dengan taraf singnifikan 5\%, karena nilai rsquare sebesar 0,007 atau setara $0,7 \%$. Akan tetapi korelasi tersebut sangat lemah sehingga diabaikan, karena nilai sebesar $99,3 \%$ tidak ada hubungan.
\end{abstract}

Kata Kunci: Hasil Belajar, Kebugaran Jasmani, Persepsi Siswa

\section{ABSTRAC}

This study aims to determine the relationship of physical fitness levels and student perceptions of student learning outcomes. This research was conducted using the correlational method. The population and sample used were all students who participated in jasmni education learning, namely 41 male students and 34 female students to 75 students. The research instruments were 16-19 years TKJI and questionnaires. Based on the results of data processing, it is concluded that: 1). There is no significant relationship between TKJI on student learning outcomes in physical education learning that is with a value of -0.665> rtable 0.514 with a level of $5 \%$, because the rsquare value of 0.006 or equivalent to $0.6 \%$, the correlation is very weak so it is ignored, because the value of $99.4 \%$ there is no relationship 2). There is no significant relationship between students' perceptions of student learning outcomes in physical education learning that is with a score of -0.191 <rtable 0.849 with a level of 5\%, so it can be concluded there is no relationship because the rsquare value of 0,000 or equal to 0.0\%, 3). There is no significant relationship between TKJI and students' perceptions of student learning outcomes in teaching educational services that is with $r$ count $-0,678>$ rtable 0,500 and $r$ count $-0,267<$ rtable 0,790 with a significance level of 5\%, because the rsquare value is 0,007 or equal to 0,7\%. However, the correlation is so weak that it is ignored, because a value of 99.3\% has no relationship.

Keyword: Learning Outcomes, Physical Fitness, Student Perception

Alamat Korespondensi: STKIP Pasundan

(C) 2020 STKIP Pasundan

Email: akhmadsobarna9@gmail.com

ISSN 2721-5660 (Cetak) 


\section{PENDAHULUAN}

Kebugaran jasmani sangat diperlukan oleh manusia, karena faktor tersebut sangat menunjang hasil aktivitas yang kita lakukan. Maka dari itu kebugaran jasmani yang berkaitan dengan diri seseorang siswa merupakan aspek penting yang harus di jaga. Untuk mempertahankan kebugarannya, siswa dituntut untuk dapat mengatur pola hidupnya dengan teratur berolahraga atau menghindari makanan yang tidak sesuai dengan tubuhnya, dengan begitu siswa akan memiliki tingkat kebugaran jasmani yang ingin dimilikinya sehingga dapat memaksimalkan pikiran dan tenaganya untuk beraktivitas disekolah. Kebugaran Jasmani (KJ) adalah derajat sehat dinamis seseorang yang menjadi kemampuan dasar untuk dapat melaksanakan tugas yang harus dilaksanakan (Giriwijoyo, H \& Zafar, S, 2012). Pengertian kebugaran jasmani secara umum sering diartikan sebagai derajat kemampuan seseorang untuk menjalankan tugas dengan derajat dan intensitas moderat tanpa mengalami kelelahan yang berlebihan hingga kemudian ia masih mampu menjalankan tugas berikutnya (Rusli Lutan, 2002). Kebugaran jasmani merupakan kondisi jasmani yang dapat menggambarkan kemampuan jasmani seseorang untuk dapat melakukan suatu pekerjaan tertentu dengan baik tanpa mengakibatkan kelelahan (Widiastuti, 2015).

Persepsi merupakan hal yang sangat penting karena lewat persepsi ini akan diketahui anggapan siswa terhadap pendidikan jasmani. Sebelum siswa melakukan kegiatan pembelajaran pendidikan jasmani ada baiknya bagi seorang guru pendidikan jasmani mengetahui terlebih dahulu persepsi siswa terhadap pendidikan jasmani yang nantinya akan ada pengaruhnya terhadap pembelajaran tersebut. Persepsi adalah pengalaman tentang obyek, peristiwa atau hubungan-hubungan yang diperoleh dengan menyimpulkan informasi dan menafsirkan pesan (Jalaludin Rahmat, 2003). Persepsi terjadi dimulai dari menghimpun atau mengumpulkan informasi yang masuk dan diseleksi untuk memperoleh prioritas. selanjutnya, informasi tersebut diorganisasikan untuk memberikan pandangan yang teratur sebelum diinterpretasikan (Chaplin, J. P, 2008). Disini jelaslah bahwa persepsi itu merupakan anggapan dari seseorang dalam memahami informasi tentang lingkungannya melalui panca indera seperti halnya siswa dalam berargumen tentang pendidikan jasmani dari segi tujuan, landasan dan manfaat melalui pengliahatan dan pendengaran mereka.

Berhasil tidaknya proses belajar mengajar pendidikan jasmani di sekolah sesuai dengan tujuan yang diharapkan ditentukan oleh banyak faktor baik dari internal maupun dari eksternal. Faktor internal yang berasal dari dalam diri siswa yang mempengaruhi keberhasilan dalam belajar diantaranya yaitu kondisi fisiologis, kondisi psikologis, kecerdasan (intelegensi) dan kematangan sedangkan faktor eksternal yang berasal dari luar diri siswa diantaranya yaitu lingkungan alam dan lingkungan sosial yang meliputi keluarga, masyarakat dan sekolah. Kondisi psikologis salah satunya adalah persepsi. Hasil belajar adalah hasil akhir yang telah diperoleh dan 
dicapai oleh seseorang dalam melakukan kegiatan. Hasil belajar dibedakan menjadi tiga aspek yaitu kognitif, afektif, dan psikomotorik (Suharsimi Arikunto, 2008:110). Penilaian hasil belajar siswa bagi kebanyakan orang berarti hasil ujian yang dilaksanakan untuk memperoleh suatu nilai dalam menentukan berhasil atau tidaknya siswa dalam belajar (Poerwodarminto, 2003). Jadi prestasi belajar penjas adalah penguasaan pengetahuan dan keterampilan yang dikembangkan pelajaran penjas.

Berdasarkan hal tersebut penulis tertarik untuk meneliti tentang "Hubungan Tingkat Kebugaran Jasmani Dan Persepsi Siswa Terhadap Prestasi Belajar Siswa Dalam Pembelajran Penjasorkes Dilingkungan Madrasah Aliyah Husainiyah Kabupaten Bandung Tahun Ajaran 2017/2018". Sehingga tujuan dari penelitian ini adalah untuk mengetahui hubungan tingkat kebugaran jasmani dan persepsi siswa terhadap prestasi belajar penjasorkes.

\section{METODE}

Metode penelitian yang digunakan adalah deskriptif dengan pendekatan korelasional. Populasi dan sampel yang digunakan adalah seluruh siswa yang mengikuti pembelajaran pendidikan jasmni, yaitu laki-laki 41 siswa dan perempuan 34 siswa jadi sebanyak 75 orang di lakukan di MA Husainiyah Kabupaten Bandung. Desain penelitian dapat digambarkan sebagai berikut:

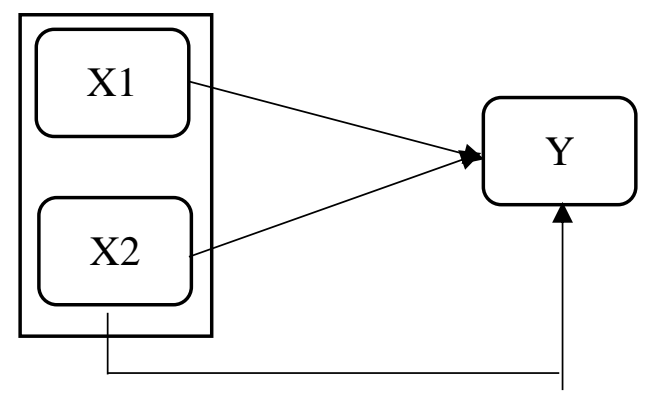

Gambar 1. Desain Penelitian

Keterangan:

$\begin{array}{ll}\mathrm{X} 1 & =\text { Kebugaran Jasmani } \\ \mathrm{X} 2 & =\text { Persepsi Siswa } \\ \mathrm{Y} & =\text { Prestasi Belajar }\end{array}$

Instrument yang digunakan dalam penelitian ini adalah menggunakan Tes Kebugaran Jasmani Indonesia (TKJI) untuk usia 16-19 tahun yang terdiri dari tes lari 60 meter, gantung angkat tubuh 60 detik, baring duduk 60 detik, loncat tegak, lari 1200 meter. Dan untuk persepsi siswa menggunakan angket tentang persepsi diri. Teknik analisis data menggunakan bantuan program SPSS 19. 


\section{HASIL PENELITIAN DAN PEMBAHASAN}

\section{Hasil Uji Korelasi $X 1$ dengan $Y$}

Hipotesis 1 yang berbunyi :

Ho:Terdapat hubungan yang signifikan antara Tes Kebugaran Jasmani dengan Hasil Belajar.

$\mathrm{Hi} \quad$ :Tidak terdapat hubungan yang signifikan antara Tes Kebugaran Jasmani dengan Hasil Belajar.

Hasil analisis dengan menggunakan bantuan program SPSS versi 21.0 diperoleh hasil sebagai berikut :

Tabel 1.

Uji Hipotesis Variabel $X_{1}$ ke Y Tabel Coefficients

Coefficients

\begin{tabular}{|c|r|r|r|r|r|}
\hline \multirow{2}{*}{ Model } & \multicolumn{2}{|l|}{ Unstandardized Coefficients } & \multicolumn{1}{c|}{$\begin{array}{c}\text { Standardized } \\
\text { Coefficients }\end{array}$} & \multirow{2}{*}{ Sig. } \\
\cline { 2 - 5 } & \multicolumn{1}{|c|}{ B } & Std. Error & \multicolumn{1}{c|}{ Beta } & \\
\hline (Constant) & 81,964 & 3,520 & & 23,284 &, 000 \\
TKJI_X1 &,- 134 &, 204 &,- 077 &,- 656 &, 514 \\
\hline
\end{tabular}

Dari tabel di atas, dapat diketahui hasil analisis regresi diperoleh koefisien untuk variabel TKJI sebesar(-0,134) dengan konstanta sebesar $(81,964)$, Sehingga model persamaan regresi yang diperoleh adalah sebagai berikut:

$$
Y 1=81,964-0,134 X 1
$$

Hasil uji empiris pengaruh TKJI terhadap Prestasi belajar menunjukkan nilai t hitung (0,656 ) dan p value (Sig) sebesar 0,514 yang di bawah alpha $5 \%$, dengan probabilitas 0,514 >0,05. Artinya bahwa Terdapat hubungan yang "negatif"antara Tes Kebugaran Jasmani dengan Hasil Belajar.

Tabel 2.

Uji Hipotesis Variabel $X_{1}$ ke Y Tabel Model Summary

Model Summary

\begin{tabular}{|l|r|r|r|r|}
\hline Model & $\mathrm{R}$ & R Square & $\begin{array}{c}\text { Adjusted R } \\
\text { Square }\end{array}$ & $\begin{array}{c}\text { Std. Error of } \\
\text { the Estimate }\end{array}$ \\
\hline 1 &, $077^{\mathrm{a}}$ &, 006 &,- 008 & 3,137 \\
\hline
\end{tabular}

Dari output di atas diketahui model koefisien $\mathrm{R}$ square sebesar 0,006, besaran angka koefisien determinasi tersebut 0,6\%. Angka tersebut mengandung arti bahwa Pengaruh TKJI terhadap Hasil Belajar sebesar 0,6\% sedangkan sisanya 99,4\% tidak ada Pengaruh TKJI terhadap Hasil Belajar. 
Tabel 3.

Uji Hipotesis Variabel $X_{1}$ ke Y Tabel Anova

\begin{tabular}{|rl|r|r|r|r|r|}
\hline \multicolumn{1}{|l|}{ Model } & \multicolumn{1}{c|}{$\begin{array}{c}\text { Sum of } \\
\text { Squares }\end{array}$} & df & Mean Square & \multicolumn{1}{|l|}{ F } & \multicolumn{1}{c|}{ Sig. } \\
\hline \multirow{2}{*}{1} & Regression & 4,236 & 1 & 4,236 &, 430 &, $514^{\mathrm{b}}$ \\
& Residual & 718,431 & 73 & 9,842 & & \\
& Total & 722,667 & 74 & & & \\
\hline
\end{tabular}

Berdasarkan output di atas diketahui bahwa nilai signifikansi dalam uji F, F hitung $<$ F tabel $=0,430<0,514$, sehingga dapat di simpulkan bahwa tidak ada pengaruh yang signifikan antara TKJI dengan Hasil Belajar.

\section{Hasil Uji Korelasi X2 dengan $Y$}

Hipotesis 2 yang berbunyi :

Ho:Terdapat hubungan yang signifikan antara Persepsi Siswa dengan Hasil Belajar.

Hi :Tidak terdapat hubungan yang signifikan antara Persepsi Siswa dengan Hasil Belajar.

Hasil analisis dengan menggunakan bantuan program SPSS versi 21.0 diperoleh hasil sebagai berikut :

Tabel 3.

Uji Hipotesis Variabel $X_{2}$ ke $Y$ Tabel Coefficients

Coefficients ${ }^{a}$

\begin{tabular}{|rl|r|r|r|r|r|}
\hline \multicolumn{2}{|l|}{ Model } & \multicolumn{2}{|l|}{ Unstandardized Coefficients } & \multicolumn{1}{c|}{$\begin{array}{c}\text { Standardized } \\
\text { Coefficients }\end{array}$} & \multirow{2}{*}{ Sig. } \\
\cline { 3 - 6 } & \multicolumn{1}{|c|}{ B } & Std. Error & \multicolumn{1}{c|}{ Beta } & \\
\hline \multirow{2}{*}{1} & (Constant) & 80,323 & 3,465 & & 23,184 &, 000 \\
& PERSEPSI_X2 &,- 004 &, 021 &,- 022 &,- 191 &, 849 \\
\hline
\end{tabular}

Dari tabel di atas, dapat diketahui hasil analisis regresi diperoleh koefisien untuk variabel Persepsi Siswa sebesar(-0,004) dengan konstanta sebesar $(80,323)$, Sehingga model persamaan regresi yang diperoleh adalah sebagai berikut:

$$
Y 1=80,323-0,004 X 1
$$

Hasil uji empiris pengaruh Persepsi siswa terhadap Hasil belajar menunjukkan nilai t hitung $(-0,191)$ dan $p$ value (Sig) sebesar 0,849 yang di bawah alpha 5\%, dengan probabilitas 0,849 $>0,05$. Artinya bahwa Tidak terdapat hubungan yang signifikan antara Persepsi Siswa dengan Hasil Belajar. 
Tabel 4.

Uji Hipotesis Variabel $X_{2}$ ke $Y$ Tabel Model Summary

\begin{tabular}{|l|r|r|r|r|}
\hline Model & R & R Square & \multicolumn{1}{|c|}{$\begin{array}{c}\text { Adjusted R } \\
\text { Square }\end{array}$} & $\begin{array}{c}\text { Std. Error of } \\
\text { the Estimate }\end{array}$ \\
\hline 1 &, $022^{\mathrm{a}}$ &, 000 &,- 013 & 3,146 \\
\hline
\end{tabular}

Dari output di atas diketahui model koefisien $\mathrm{R}$ square sebesar 0,000, besaran angka koefisien determinasi tersebut $0 \%$. Angka tersebut mengandung arti bahwa Pengaruh TKJI terhadap Prestasi belajar sebesar 0\% sedangkan sisanya 100\% tidak ada Pengaruh Persepsi Siswa terhadap Prestasi belajar.

Tabel 5.

Uji Hipotesis Variabel $X_{2}$ ke Y Tabel Anova

\begin{tabular}{|rl|r|r|r|r|r|}
\hline \multicolumn{2}{|l|}{ Model } & \multicolumn{1}{c|}{$\begin{array}{c}\text { Sum of } \\
\text { Squares }\end{array}$} & df & Mean Square & \multicolumn{1}{|c|}{ F } & \multicolumn{1}{c|}{ Sig. } \\
\hline \multirow{2}{*}{1} & Regression &, 359 & 1 &, 359 &, 036 & ,849b \\
& Residual & 722,308 & 73 & 9,895 & & \\
& Total & 722,667 & 74 & & & \\
\hline
\end{tabular}

\section{Hasil Uji Korelasi X1, X2 dengan $Y$}

Hipotesis 3 yang berbunyi :

Ho:Terdapat hubungan yang signifikan antara TKJI dan Persepsi Siswa secara bersamasama dengan Hasil Belajar.

Hi :Tidak terdapat hubungan yang signifikan antara TKJI dan Persepsi Siswa secara bersama-sama dengan Hasil Belajar.

Hasil analisis dengan menggunakan bantuan program SPSS versi 21.0 diperoleh hasil sebagai berikut :

Tabel 6.

Uji Hipotesis Variabel $X_{1}, X_{2}$ ke Y Tabel Coefficients

\begin{tabular}{|rl|r|r|r|r|r|}
\hline \multicolumn{2}{|l|}{ Model } & \multicolumn{2}{|c|}{ Unstandardized Coefficients } & \multicolumn{2}{c|}{$\begin{array}{c}\text { Standardized } \\
\text { Coefficients }\end{array}$} & \multirow{2}{*}{ Sig. } \\
\cline { 3 - 5 } & & B & Std. Error & Beta & & \\
\hline \multirow{2}{*}{1} & (Constant) & 83,002 & 5,262 & & 15,773 &, 000 \\
& TKJI_X1 &,- 140 &, 207 &,- 080 &,- 678 &, 500 \\
& PERSEPSI_X2 &,- 006 &, 021 &,- 032 &,- 267 &, 790 \\
\hline
\end{tabular}


Berdasarkan output di atas diketahui bahwa nilai signifikansi dalam uji F, F hitung $<$ F tabel $=0,036<0,849$, sehingga dapat di simpulkan bahwa tidak ada pengaruh yang signifikan antara Persepsi Siswa dengan Prestasi belajar.

Dari tabel di atas, dapat diketahui hasil analisis regresi diperoleh koefisien untuk variabel TKJI sebesar $(-0,140)$ Persepsi Siswa sebesar $(-0,006)$ dengan konstanta sebesar $(83,002)$, Sehingga model persamaan regresi yang diperoleh adalah sebagai berikut:

$$
Y 1=83,002-0,140 X 1-0,006 X 2
$$

Hasil uji empiris pengaruh TKJI terhadap Hasil Belajar menunjukkan nilai t hitung ($0,678)$ dan $(-0,267)$ dengan p value (Sig) sebesar $(0,500)$ dan $(0,790)$ yang di bawah alpha $5 \%$, dengan probabilitas 0,500 >0,05 dan 0,790>0,05. Artinya bahwa Terdapat hubungan yang "negatif" TKJI dan Persepsi Siswa secara bersama-sama dengan Hasil Belajar.

Tabel 7.

Uji Hipotesis Variabel $\mathrm{X}_{1}, \mathrm{X}_{2}$ ke $\mathrm{Y}$

\begin{tabular}{|l|r|r|r|r|}
\hline Model & R & R Square & $\begin{array}{c}\text { Adjusted R } \\
\text { Square }\end{array}$ & $\begin{array}{c}\text { Std. Error of } \\
\text { the Estimate }\end{array}$ \\
\hline 1 &, $083^{\mathrm{a}}$ &, 007 &,- 021 & 3,157 \\
\hline
\end{tabular}

a. Predictors: (Constant), PERSEPSI_X2, TKJI_X1

Dari output di atas diketahui model koefisien $\mathrm{R}$ square sebesar 0,007, besaran angka koefisien determinasi tersebut 0,7 \%. Angka tersebut mengandung arti bahwa ada hubungan antara TKJI dan Persepsi Siswa secara bersama-sama dengan Hasil Belajar sebesar $\quad 0,7 \%$. Sedangkan sisanya 99,3\% tidak ada hubungan antara TKJI dan Persepsi Siswa secara bersamasama dengan Hasil Belajar.

Tabel 4.21

Uji Hipotesis Variabel $X_{1}, X_{2}$ ke Y Tabel Anova

\begin{tabular}{|rl|r|r|r|r|r|}
\hline \multicolumn{1}{|l|}{ Model } & \multicolumn{1}{c|}{$\begin{array}{c}\text { Sum of } \\
\text { Squares }\end{array}$} & Df & Mean Square & \multicolumn{1}{|l|}{ F } & Sig. \\
\hline \multirow{2}{*}{1} & Regression & 4,945 & 2 & 2,473 &, 248 &, $781^{\mathrm{b}}$ \\
& Residual & 717,721 & 72 & 9,968 & & \\
& Total & 722,667 & 74 & & & \\
\hline
\end{tabular}

Berdasarkan output di atas diketahui bahwa nilai signifikansi dalam uji F, F hitung $<$ F tabel $=0,0248<0,781$, sehingga dapat di simpulkan bahwa tidak terdapat hubungan yang signifikan antara TKJI dan Persepsi Siswa secara bersama-sama dengan Prestasi Belajar. 


\section{Pembahasan}

\section{a. Tidak terdapat hubungan yang signifikan antara TKJI dengan Hasil Belajar}

Secara biologis seseorang yang memiliki tingkat kesegaran jasmani yang baik akan lebih mudah menerima informasi maupun memberikan respon dari informasi yang dia terima dari pada seseorang yang memiliki tingkat kesegaran jasmani yang kurang atau tidak baik. Dengan demikian hipotesa yang penulis ajukan adalah "Ada hubungan yang signifikan antara tingkat kesegaran jasmani terhadap hasil belajar siswa". Untuk membuktikan kebenaran hipotesa di atas maka penulis menggunakan analisis korelasi product moment Pearson.

Koefisien rxy atau ro yang sudah diperoleh yaitu -0,656, sedangkan rt sebesar 0,514 . Dengan demikian ro > rt, pada taraf signifikan 5\% dan koefisien Rsquare sebesar 0,006 atau setara 0,6\% maka ada hubungan yang signifikan antara TKJI terhadap Hasil Belajar sebesar 0,6\% dan 99,4\% tidak ada hubungan yang signifikan antara TKJI terhadap Hasil Belajar, maka hipotesa alternatif (Ho) yang berbunyi "Ada hubungan yang signifikan antara Tingkat Kesegaran Jasmani terhadap Hasil Belajar Siswa”, ditolak dan hipotesa nihilnya yang berbunyi "Tidak ada hubungan yang signifikan antara Tingkat Kesegaran Jasmani terhadap Hasil Belajar Siswa", diterima. Jadi pada taraf signifikan 5\% tidak ada hubungan yang signifikan antara Tingkat Kesegaran Jasmani terhadap Hasil Belajar Siswa-Siswi kelas X-XI-XII Maadrasah Aliyah Husainiyah Tahun Pelajaran 2017 / 2018. Maka rumusan hipotesis yang penulis ajukan ditolak.

Namun karena nilainya bertanda negatif (-) maka dapat dinyatakan bahwa dengan interpretasi secara sederhana, antara Tingkat Kesegaran Jasmani (variabel $x$ ) dan Hasil Belajar Siswa (variabel $y$ ) terdapat korelasi negatif atau berlawanan, tetapi sangat lemah. Dengan kata lain semakin baik tingkat kesegaran jasmani maka hasil belajar akan cenderung menurun. Akan tetapi korelasi tersebut sangat lemah sehingga diabaikan (dianggap tidak ada korelasi antara Tingkat Kesegaran Jasmani dan Hasil Belajar Siswa). Hasil penelitian menunjukkan tidak adanya hubungan yang signifikan antara tingkat kesegaran jasmani terhadap hasil belajar Siswa-Siswi kelas X-XI-XII Maadrasah Aliyah Husainiyah Tahun Pelajaran 2017 / 2018 dengan instrumen tes kesegaran jasmani menurut panduan Tes Kesegaran Jasmani Indonesia (TKJI) oleh Pusat Pengembangan Kualitas Jasmani, untuk kategori anak usia 16-19 tahun.

\section{b. Tidak terdapat hubungan yang signifikan antara Persepsi Siswa dengan Hasil Belajar}

Secara biologis seseorang yang memiliki Persepsi Siswa yang baik akan lebih mudah menerima informasi maupun memberikan respon dari informasi yang dia terima dari pada seseorang yang memiliki Persepsi Siswa yang kurang atau tidak baik. Dengan demikian hipotesa yang penulis ajukan adalah "Ada hubungan yang signifikan antara persepsi siswa terhadap hasil belajar siswa". Untuk membuktikan kebenaran hipotesa di atas maka penulis menggunakan analisis korelasi product moment Pearson. Koefisien rxy atau ro yang sudah diperoleh yaitu - 
0,191, sedangkan rt sebesar 0,849. Dengan demikian ro > rt, pada taraf signifikan $5 \%$ dan koefisien Rsquare sebesar 0,000 atau setara 0\% maka ada hubungan yang signifikan antara Persepsi Siswa terhadap hasil Belajar sebesar 0\% dan 100\% tidak ada hubungan yang signifikan antara Persepsi Siswa terhadap Prestasi Belajar, maka hipotesa alternatif (Ho) yang berbunyi "Ada hubungan yang signifikan antara Persepsi Siswa terhadap hasil Belajar Siswa", ditolak dan hipotesa nihilnya yang berbunyi "Tidak ada hubungan yang signifikan antara Persepsi Siswa terhadap Prestasi Belajar Siswa", diterima. Jadi pada taraf signifikan 5\% tidak ada hubungan yang signifikan antara Persepsi Siswa terhadap Prestasi Belajar Siswa-Siswi kelas X-XI-XII Maadrasah Aliyah Husainiyah Tahun Pelajaran 2017 / 2018. Maka rumusan hipotesis yang penulis ajukan ditolak.

Hasil penelitian menunjukkan tidak adanya hubungan yang signifikan antara persepsi siswa terhadap hasil belajar Siswa-Siswi kelas X-XI-XII Maadrasah Aliyah Husainiyah Tahun Pelajaran 2017 / 2018 dengan instrumen angket persepsi siswa dan Hasil belajar.

\section{c. Tidak terdapat hubungan yang signifikan antara TKJI dan Persepsi Siswa secara bersama-sama dengan Hasil Belajar.}

Secara umum berdasarkan hasil kedua analisa di atas maka dapat dikatakan hubungan tingkat kesegaran jasmani dan Persepsi Siswa secara bersama-sama dengan hasil belajar siswasiswi kelas X-XI-XII Maadrasah Aliyah Husainiyah Tahun Pelajaran 2017 / 2018, ketiganya berkatagori sedang dan baik sekali. Namun adakah hubungan yang signifikan antara tingkat kesegaran jasmani dan Persepsi Siswa secara bersama-sama dengan prestasi belajar siswa?

Secara biologis seseorang yang memiliki tingkat kebugaran jasmani dan persepsi siswa yang baik akan lebih mudah menerima informasi maupun memberikan respon dari informasi yang dia terima dari pada seseorang yang memiliki tingkat kebugaran jasmani dan persepsi siswa yang kurang atau tidak baik. Dengan demikian hipotesa yang penulis ajukan adalah "ada hubungan yang signifikan antara tingkat kesegaran jasmani dan persepsi siswa secara bersamasama dengan prestasi belajar siswa". Untuk membuktikan kebenaran hipotesa di atas maka penulis menggunakan analisis korelasi product moment pearson.

Koefisien rxy atau ro yang sudah diperoleh yaitu -0,678, dan -0,267 sedangkan rt sebesar 0,500dan 0,790. Dengan demikian ro > rt, pada taraf signifikan 5\% dan koefisien Rsquare sebesar 0,007 atau setara 0,7\%, maka ada hubungan yang signifikan antara TKJI dan Persepsi Siswa secara bersama-sama terhadap Prestasi Belajar sebesar 0,7\% dan sebesar 99,3\% tidak ada hubungan yang signifikan antara TKJI dan PersepsiSiswa secara bersama-sama terhadap Prestasi Belajar, maka hipotesa alternatif (Ho) yang berbunyi "Ada hubungan yang signifikan antara TKJI dan Persepsi Siswa secara bersama-sama dengan Prestasi Belajar", ditolak dan hipotesa nihilnya yang berbunyi "Tidak ada hubungan yang signifikan antara TKJI dan Persepsi Siswa secara 
bersama-sama dengan Prestasi Belajar", diterima. Jadi pada taraf signifikan 5\% tidak ada hubungan yang signifikan antara TKJI dan Persepsi Siswa secara bersama-sama dengan Prestasi Belajar Siswa-Siswi kelas X-XI-XII Maadrasah Aliyah Husainiyah Tahun Pelajaran 2017 / 2018. Maka rumusan hipotesis yang penulis ajukan ditolak.

Namun karena nilainya bertanda negatif (-) maka dapat dinyatakan bahwa dengan interpretasi secara sederhana, antara Tingkat Kesegaran Jasmani (variabel $x_{1}$ ) dan Persepsi Siswa (variabel $x_{2}$ ) dengan Prestasi Belajar Siswa (variabel $y$ ) terdapat korelasi negatif atau berlawanan, tetapi sangat lemah. Dengan kata lain semakin baik tingkat kesegaran jasmani dan Persepsi Siswa maka prestasi belajar akan cenderung menurun. Akan tetapi korelasi tersebut sangat lemah sehingga diabaikan (dianggap tidak ada korelasi antara Tingkat Kesegaran Jasmani dan Persepsi Siswa secara bersama-sama dengan Prestasi Belajar Siswa).

Hasil penelitian menunjukkan tidak adanya hubungan yang signifikan antara Tingkat Kesegaran Jasmani dan Persepsi Siswa secara bersama-sama dengan Prestasi Belajar Siswa-Siswi kelas X-XI-XII Maadrasah Aliyah Husainiyah Tahun Pelajaran 2017 / 2018 dengan instrumen tes kesegaran jasmani menurut panduan Tes Kesegaran Jasmani Indonesia (TKJI) oleh Pusat Pengembangan Kualitas Jasmani, untuk kategori anak usia 16-19 tahun, angket persepsi siswa, dan Prestasi belajar (hasil UTS semester 1).

Dari hasil ke 3 hipotesis yang ada, dengan melihat tinjauan teori bahwa faktor fisiologis yang mempengaruhi hasil belajar siswa adalah faktor kesehatan dan faktor cacat badan, bukan tingkat kesegaran jasmani dan Persepsi. Faktor kesehatan di sini berarti keadaan sehat atau sakit. Anak yang sakit atau dalam keadaan lemah akan sukar belajar dan anak yang cacat badan harus mendapatkan pendidikan secara khusus. (Slameto, 2010:54)

Dengan demikian anak yang tingkat kesegaran jasmani dan persepsinya rendah pun dapat memperoleh hasil belajar yang baik apabila memiliki kesehatan yang baik (keadaan fit atau tidak sakit) dan Fikiran yang Positif. Hal ini karena adanya faktor psikologis yang lebih dominan.

Hal ini sesuai dengan pernyataan Slameto (Slameto, 2010:54) yang mengatakan bahwa Berhasil atau tidaknya belajar itu tidak hanya ditentukan oleh kemampuan intelektual saja, tetapi juga dipengaruhi oleh bermacam-macam faktor. Adapun faktor psikologis yang yang mempengaruhi hasil belajar yaitu sikap, bakat, minat dan motivasi. Dengan demikian apabila tingkat kesegaran jasmani dan persepsi dihubungkan dengan hasil belajar untuk UTS semester 1 sangat lemah sekali. Bahkan setelah diadakan penelitian ini hasilnya justru berlawanan karena hasil perhitungan korelasi menunjukkan tanda negatif (-). Dengan kata lain anak yang memiliki tingkat kesegaran jasmani dan persepsi yang tinggi cenderung hasil belajarnya lebih rendah dari pada yang anak yang memiliki tingkat kesegaran jasmani dan persepsi yang biasa-biasa saja. Hal ini mungkin disebabkan karena anak yang memiliki tingkat kesegaran jasmani dan persepsi yang tinggi cenderung lebih menyukai kegiatan-kegiatan dan fisik di luar rumah seperti bermain atau 
olahraga dibandingkan dengan anak yang memiliki tingkat kesegaran jasmani dan persepsi yang biasa-biasa saja atau rendah cenderung lebih menyukai kegiatan-kegiatan yang ringan seperti membaca buku atau majalah. Namun pendapat ini masih perlu dibuktikan pada penelitian berikutnya.

\section{KESIMPULAN}

Berdasarkan hasil penelitian dan analisis data yang peneliti laksanakan tentang "Hubungan Tingkat Kesegaran Jasmani dan persepsi siswa Terhadap Prestasi Belajar Pada SiswaSiswi kelas X-XI-XII Maadrasah Aliyah Husainiyah Tahun Pelajaran 2017 / 2018” dapat diambil kesimpulan sebagai berikut:

1. Tidak ada hubungan yang signifikan antara Tingkat Kesegaran Jasmani dengan Hasil Belajar Siswa.

2. Tidak ada hubungan yang signifikan antara Persepsi siswa dengan Hasil Belajar Siswa.

3. Tidak ada hubungan yang signifikan antara Tingkat Kesegaran Jasmani dan Persepsi Siswa secara bersama-sama dengan hasil Belajar Siswa.

\section{DAFTAR PUSTAKA}

Arikunto, Suharsimi. (2008). Prrosedur Penelitian Suatu Pendekatan Praktek. Jakarta: Rineka Cipta.

Chaplin, J. P. (2008), Kamus Lengkap Psikologi. Jakarta: PT. Raja Grafindo Persada.

Giriwijoyo, H \& Zafar, S. (2012). Ilmu Faal Olahraga. Bandung: PT. Remaja Rosdakarya.

Jalaluddin Rahmat. (2009). Psikologi Komunikasi. Bandung: Remaja Rosdakarya.

Lutan, Rusli. (2002). Menuju Sehat Dan Bugar. Jakarta: Depdiknas.

Poerwodarminto. (2003). Kamus Umum Bahasa Indonesia (KUBI). Jakarta: Balai Pustaka.

Slameto. (2010). Belajar dan Faktor-Faktor Yang Mempengaruhinya. Jakarta: Rineka Cipta.

Widiastuti. (2015). Tes dan Pengukuran Olahraga. Jakarta: PT. Raja Grafindo Persada. 